\title{
Od parowozu do lux-torpedy - cz.II. Spawanie w naprawach i produkcji taboru kolejowego (z teki Jacka Lassocińskiego)
}

\section{From the steam engine to the lux-torpedoes - part II. Gas welding in the repair of railway rolling stock, (from Jacek Lassociński's portfolio)}

\section{Streszczenie}

W artykule przedstawiono możliwości wykorzystania spawania elektrycznego w naprawach taboru kolejowego, w tym do naprawy kotłów, palenisk, cylindrów i ścian sitowych parowozu. Przedstawiono również przykłady spawanych lokomotyw, wagonów osobowych i towarowych, a także wagonów motorowych, tzw. lukstorped.

\section{Wstęp}

Warsztaty kolejowe odegrały dużą rolę w rozwoju spawania łukowego. W 1920 r. Warsztaty Kolejowe we Lwowie otrzymały spawarkę łukową i elektrody kupione w Stanach Zjednoczonych przez delegację rządu polskiego pod przewodnictwem I. Paderewskiego. Załoga Warsztatów nie miała żadnego doświadczenia spawalniczego, mimo to uruchomiono spawarkę w oparciu o instrukcje w j. angielskim i rozpoczęto naprawy uszkodzonych parowozów [7]. W tym samym czasie (1921) powstała spawalnia „elektrołukowa” w Głównych Warsztatach Kolejowych w Poznaniu [5], Krakowskich Warsztatach PKP (1922) oraz w Warszawskiej Wytwórni Parowozów, w której w 1925 r. pracowało już 15 spawaczy i była to największa spawalnia kolejowa w Polsce [8].

Warsztaty kolejowe były wyposażone głównie w urządzenia firmy Wilson-Welder \& Metals Co. New York, AEG Union Berlin, Akt. Bolag Wex Stockholm i La Soundure Electrique Autogene Bruksela [1, 6].

Urządzenia Wilson-Weder służyły do spawania prądem stałym, otrzymywanym z przetwornika, składającego się z silnika trójfazowego o mocy 7,5 KM,

Dr inż. Anna Pocica - Politechnika Opolska.

\section{Abstract}

The paper presents the possibility of using electric welding to repair of rolling stock, including the repair of boilers, furnaces, cylinders and tube-sheets in steam locomotives. It also presents examples of welded steam locomotives, carriages, wagons and motor cars called lux-torpedoes. który był sprzężony bezpośrednio z prądnicą prądu stałego. Urządzenia Wexa były urządzeniami trójfazo-

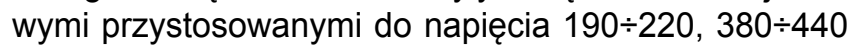
i $500 \mathrm{~V}$, natomiast nowością były urządzenia La Soundure Electrique. Były to maszyny prądu przemiennego, bez silnika i przetwornika, prąd był pobierany z sieci i przepuszczany przez transformator, z którego uzyskiwano prąd do spawania o napięciu $25 \div 35 \mathrm{~V}$ i natężeniu $100 \div 500$ A $[1,6]$

Po I wojnie światowej przy budowie parowozów spawania łukowego było niewiele, natomiast stosowano je szeroko do napraw starych wraków pozostawionych przez zaborców. Między innymi wykonywano: naprawy palenisk, połączenia rur ze ścianą sitową, łączenie pękniętych ram podwozia i szprych kół parowozowych, naprawy pękniętych cylindrów, a także regenerowano zużyte części, także przez napawanie [1].

Najczęściej występującym zużyciem paleniska było nadpalenie krawędzi otworu drzwiczkowego i pękanie blachy między nitem i krawędzią (rys. 1a). Miejsce, w którym występowało pęknięcie, ukosowano, a następnie spawano. Gdy pęknięcie występowało po obu stronach nitu, usuwano nit, a otwór po nim również ukosowano (rys. 1b). Jednostronne pęknięcia, zamaskowane przez główkę nitu, ukosowano, wycinając także część główki. Po spojeniu pęknięć „zalewano” spoiwem główki nitów nieusuniętych i otwory po nitach 

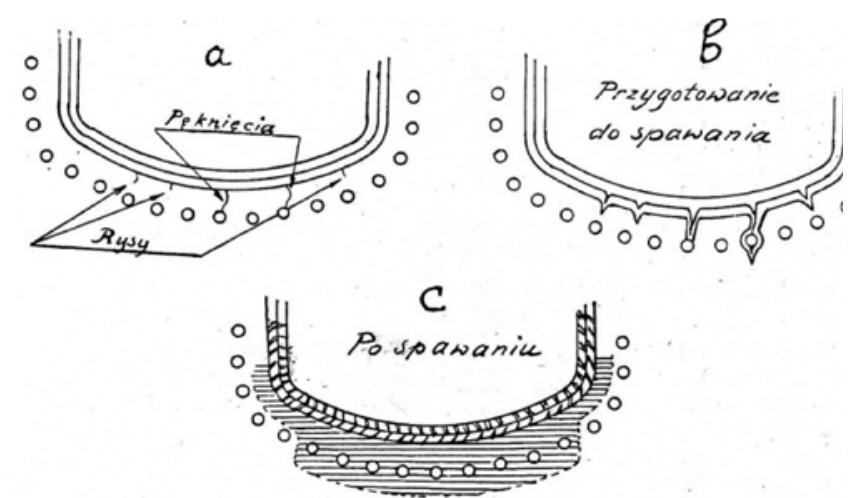

Rys. 1. Sposób naprawy otworu drzwiczkowego paleniska [3] Fig. 1. Furnace door-way repair method [3]

Tablica I. Parametry spawania w zależności od grubości blach [6] Table I. Welding parameters for different plate thickness [6]

\begin{tabular}{|c|c|c|c|}
\hline $\begin{array}{c}\text { Grubość } \\
\text { blachy, mm }\end{array}$ & $\begin{array}{c}\text { Średnica } \\
\text { elektrody, mm }\end{array}$ & $\begin{array}{c}\text { Natężenie, } \\
\text { A }\end{array}$ & $\begin{array}{c}\text { Długość spoiny } \\
\text { uzyskana w ciągu } \\
1 \mathrm{~h}, \mathrm{~m}\end{array}$ \\
\hline $6-8$ & 4 & $100-120$ & $3-4$ \\
$9-12$ & 4 & $120-140$ & $2-3$ \\
$14-18$ & 5 & $140-160$ & $1-2$ \\
Ponad 18 & 6 & $160-180$ & 0,6 \\
\hline
\end{tabular}

usuniętych, a następnie kładziono spoinę na krawędzi otworu drzwiczkowego (rys. 1c) i wiercono otwory na nowe nity [3].

Jeżeli wskutek silnego zużycia lub pęknięć należało wymienić część blachy paleniska, wycinano zniszczony materiał, a w jego miejsce wstawiano łaty. Krawędź pozostałą po wycięciu oraz łatę ukosowano pod kątem $45^{\circ}$, wstawiano łatę w powstały otwór, po czym spawano jedno- lub dwustronnie, o ile istniała taka możliwość. Wielkość łaty była tak dobierana, by prześwit z każdej strony między jej krawędzią a krawędzią otworu wynosił $3 \mathrm{~mm}$ [6]. Parametry spawania oraz średnice użytych elektrod zależały od grubości blachy (tabl. I).

Po spawaniu elektrycznym wytrzymałość na rozciąganie złącza wynosiła $80 \%$ wytrzymałości materiału rodzimego, podczas gdy po spawaniu acetylenowym $61 \%$, a po nitowaniu $58 \%$ [6].

Warsztaty kolejowe we Lwowie już po 3 latach od uruchomienia spawarki prowadziły duże naprawy kotłów za pomocą spawania elektrycznego. $W$ ramach napraw głównych wstawiano łaty w ścianie drzwiczkowej paleniska (rys. 2), łaty na ścianach bocznych (rys. 3) oraz na ścianach sitowych (rys. 4) [6, 9].

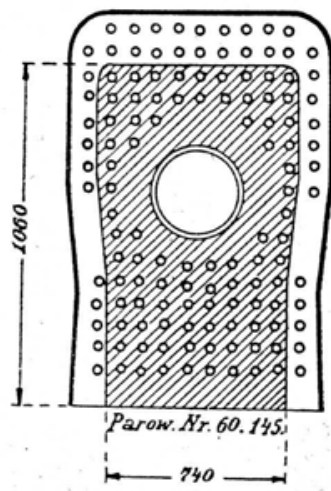

Rys. 2. Wstawianie łat na ścianie drzwiczkowej paleniska [6]

Fig. 2. Patch placement in doorwall of furnace [6]
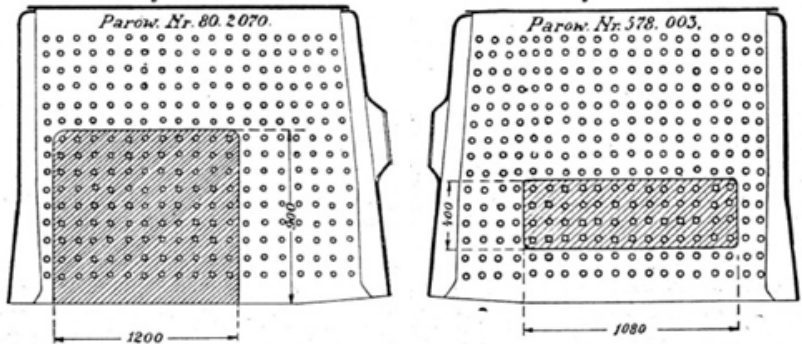

Rys. 3. Wstawianie łat na bocznych ścianach paleniska [9]

Fig. 3. Patch placement in side-walls of furnace [9]
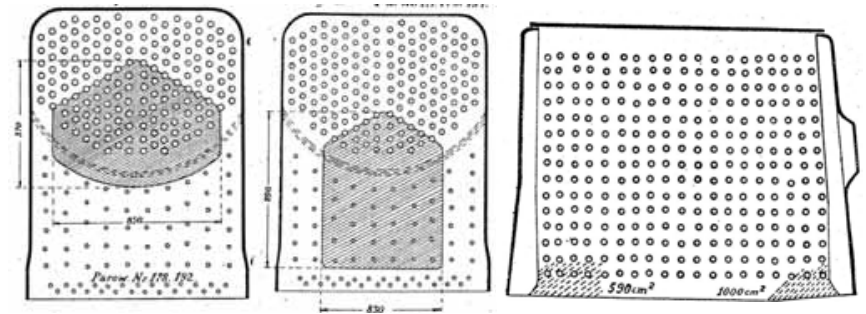

Rys. 4. Wstawianie łat na ścianach sitowych [9]

Fig. 4. Patch placement in tube-sheets [9] a)

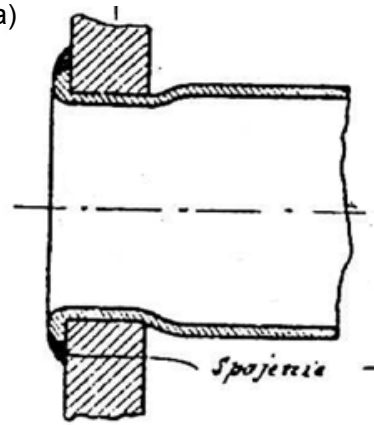

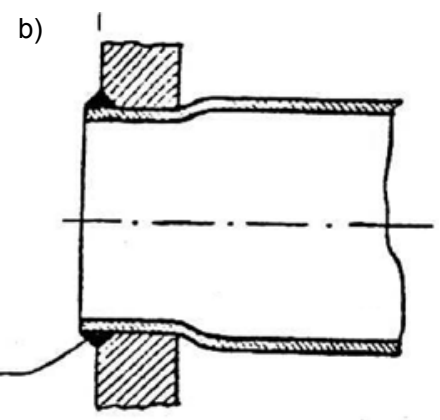

b)

Rys. 5. Metody łączenia rur płomieniowych ze ścianami sitowymi [9] Fig. 5. Combustion tubes and tube-sheet joining methods [9]

Stosowano również spawanie elektryczne do łączenia rur płomieniowych ze ścianami sitowymi. Początkowo testowano dwie metody łączenia (rys. 5) [9]. W pierwszej w rurach walcowano kołnierze (rys. 5a), po czym brzeg kołnierza spajano ze ścianą sitową, w drugiej spawano rury bez kołnierza (rys. 5b). Lepsze okazało się pierwsze rozwiązanie, więc $z$ drugiego zrezygnowano [7].

a)

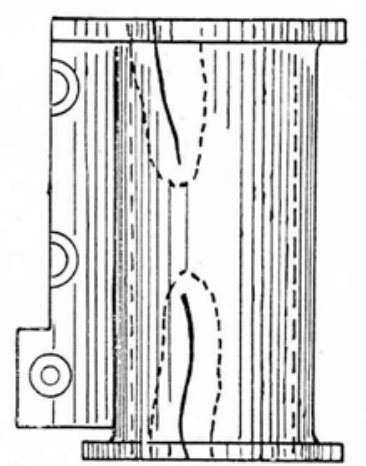

b)

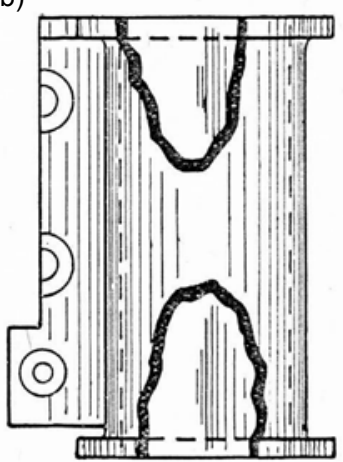

Rys. 6. Cylinder przeznaczony do naprawy [11]: a) zaznaczone fragmenty do wycięcia, b) po odwierceniu i usunięciu odłamków

Fig. 6. Cylinder to repair [11]: a) marked parts to cut out; b) after drilling and damaged metal removing 
Przy wymianie rur płomieniowych spawanych elektrycznie wycinano starą spoinę, ścianę wygładzano i przygotowywano ją do spawania za pomocą specjalnych frezów, po czym postępowano tak jak opisano powyżej.

W Polsce jedynym zakładem wykonującym naprawy cylindrów parowozowych były Warsztaty Kolejowe Poznańskie. Rocznie spawano tam 100 pękniętych cylindrów.

Uszkodzone cylindry czyszczono parą i gorąca wodą z ługiem, a następnie wycinano materiał wokół pęknięcia, poprzez nawiercenie części i usunięcie materiału przecinakiem pneumatycznym (rys. 6) [11].

Przed spawaniem usunięty fragment odformowywano na cylindrze. Do cylindra za pomocą specjalnych sztyftów montowano rusztowanie składające się z metalowych kształtowników. Do rusztowania mocowano blachy, okalające pęknięte miejsca i służące za oparcie płytek węglowych. Płytki te wstawiano do piasku formierskiego, który zapełniał przestrzeń między płytka$\mathrm{mi}$, a okalającą blachą. Po odformowaniu wyciętej części cylindra rozdzielano ją płytkami na $2 \div 3$ lub więcej

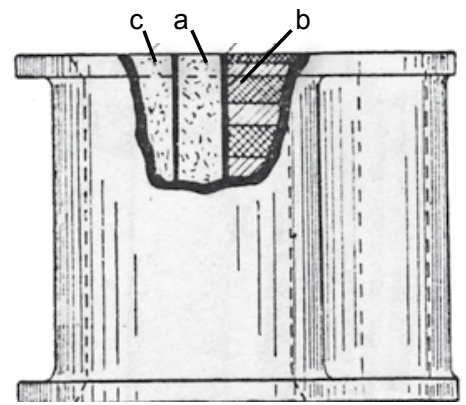

Rys. 7. Schemat spawania cylindra [11]: a - przegrody z płytek ogniotrwałych, $b$ - komory zapełnione piaskiem, c - komora zalewana; pojedyncze kreski - materiał elektrody, podwójne kreski - materiał dolany

Fig. 7. Scheme of cylinder welding [11]: a - division made by fireresistant plates; $b$ - chamber with sand, $c$ - flooded chamber; single lines - electrode metal, double lines - added metal

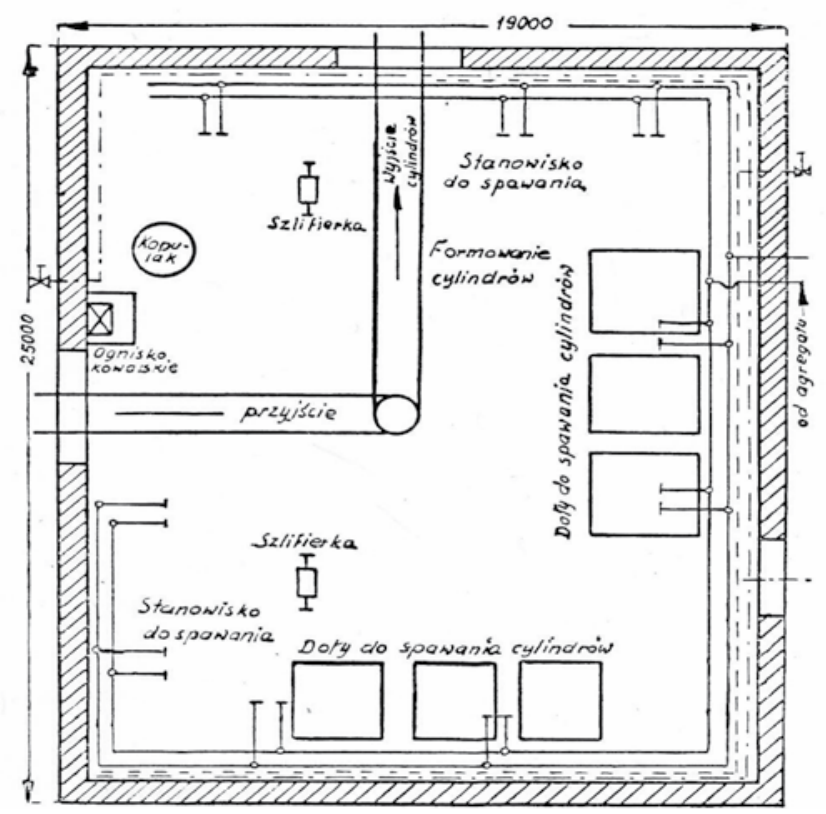

Rys. 8. Plan spawalni Warsztatów Poznańskich [11]

Fig. 8. Welding shop plan in Warsztaty Poznańskie [11] „działek” (rys. 7), po czym cylinder opuszczano do dołu spawalniczego (rys. 8), gdzie nagrzewano go węglem drzewnym przez $2 \div 3$ godziny.

Do spawania cylindrów stosowano elektrody własnej produkcji, odlane w specjalnych formach. W skład tych elektrod wchodziło $25 \%$ surówki, $60 \%$ złomu żeliwnego i 15\% złomu staliwnego. Do spawania grubszych odlewów używano elektrod o średnicy $13 \mathrm{~mm}$, a do cieńszych o średnicy $8 \mathrm{~mm}$. Po połączeniu bieguna dodatniego do cylindra, a ujemnego do uchwytu spawalniczego rozpoczynano spawanie w pierwszej działce. Łuk topił elektrodę i krawędź wycięcia. Do spawania wycięcia o wielkości $0,2 \mathrm{~m}^{2}$ potrzeba było $100 \mathrm{~kg}$ żeliwa i przy natężeniu $450 \mathrm{~A}$ ok. 30 godzin pracy dwóch robotników. W celu ułatwienia i potanienia procesu w miejsce spawania dolewano $5 \div 20 \mathrm{~kg}$ ciekłego żeliwa. Żeliwo to, otrzymywane w tzw. kopulakach (żeliwiakach), miało skład chemiczny taki sam jak elektrody spawalnicze. Po wlaniu żeliwa spawacz ogrzewał je łukiem, co pozwalało na wymieszanie go z materiałem stopionej elektrody. Dodawanie ciekłego żeliwa i rozgrzewanie go łukiem powtarzano kilka razy, do momentu wypełnienia działki. Tak samo postępowano z działkami 2 i 3 . Po ukończeniu spawania miejsce spawane zabezpieczano blachą, a cylinder zasypywano ziemią, pod którą stygł $5 \div 6$ dni [12].

Koszty naprawy cylindrów, w porównaniu z ceną cylindrów nowych, przedstawiono na rysunku 9 [12].

Spawanie elektryczne stosowano również do naprawy zestawów kołowych taboru [13]. Spawano pęknięte szprychy kół i pęknięcia wieńca koła bosego oraz napawano osie wagonowe i parowozowe, czopy korbowe i wiązarowe, podpiasty osi, wytarte piasty na wewnętrznych czołowych powierzchniach, a także wytarte i podcięte obrzeża obręczy. Wytrzymałość uzyskanych połączeń wynosiła

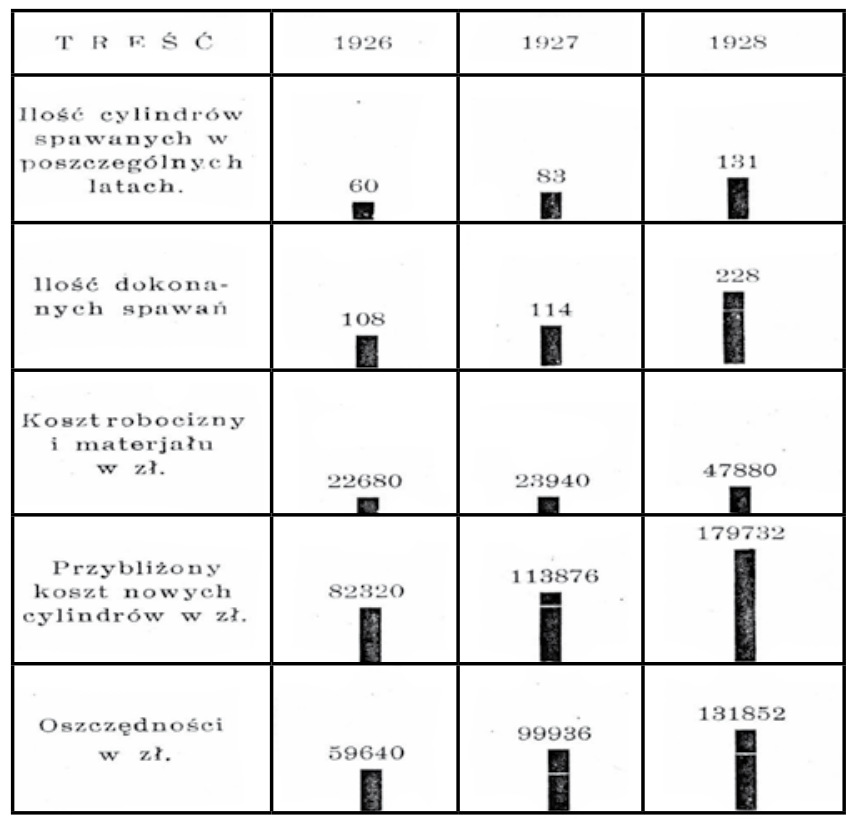

Rys. 9. Koszty naprawy cylindrów w latach 1926-1928 [12]

Fig. 9. Cylinder repair costs in 1926-1928 [12] 
$85 \div 100 \%$ wytrzymałości materiału rodzimego, natomiast plastyczność była niewielka [13].

Szczególne znaczenie dla gospodarki miało napawanie obręczy kół. Tradycyjna metoda naprawy obręczy wymagała demontażu i przetoczenia wszystkich kół. Samo wyciąganie zestawu kołowego kosztowało ok. 300 zł i trwało 5 dni. Stosując spawanie, naprawę wykonano bez demontażu i trwała ona tylko 3 godziny przy kosztach ok. 20 zł [14].

Korzyści płynące z wykorzystania spawania do napraw i regeneracji elementów wagonów i parowozów, a także tendencja do coraz szerszego stosowania metali zamiast drewna, skłoniły konstruktorów do zastosowania spawania w budowie taboru kolejowego. Monolityczny charakter konstrukcji spawanych sprawił, że przy tej samej wytrzymałości były one lżejsze i sztywniejsze niż nitowane.

Wagon węglarka nitowany o ładowności 63,5 t ważył $27 \mathrm{t}$, podczas gdy wagon spawany, o tej samej ładowności, tylko $22 \mathrm{t}$, czyli tyle, ile ważył wagon nitowany o ładowności 45,5 t. Tak więc, przy tym samym ciężarze własnym można było przewieźć $18 \mathrm{t}$ więcej węgla. W porównaniu z najlżejszym nitowanym wagonem innych konstrukcji, o znacznie zmniejszonej pojemności, oszczędność masy wynosiła 8,6\%, a zwiększenie pojemności 8,9\% [15].

O wyborze metody spawania decydował rodzaj wykonywanego obiektu oraz jego przeznaczenie, a także koszt wytwarzania [16].

Spawanie łukowe, przy ówczesnym stanie techniki, mogło być tańsze od acetylenowo-tlenowego tylko przy bardzo niskich cenach prądu i przy pracach podrzędnych, niewymagających drogich elektrod otulonych. W związku z tym elementy o większych przekrojach spawano acetylenem, a łuk stosowano jedynie do cieńszych blach [15].

W Polsce spawanie w budowie taboru kolejowego wprowadzono na początku lat trzydziestych ubiegłego wieku [17]. Etapem pośrednim do wprowadzenia wagonów całkowicie spawanych były wagony-meblarki, wykonane w Zakładach Ostrowieckich, które miały spawane pudło i, na żądanie Ministerstwa Komunikacji, nitowane podwozie [18]. Spawanie zastosowano również w tych Zakładach do budowy pługów do odśnieżania typu Björk. Dzięki zastosowaniu spawania osiągnięto bardzo wytrzymałą konstrukcję, gdyż ostoja, szkielet pudła i płaszcz tworzyły jedną całość, dającą gwarancję pełnej sztywności. Uzyskanie, w wyniku spawania, gładkich powierzchni pozwoliło na zminimalizowanie oporu.

Ponadto gładka powierzchnia i szczelność połączenia zmniejszały niebezpieczeństwo korozji. Właśnie ze względu na korozję w Zakładach Lilpop, Rau i Loewenstein stosowano spawanie łukowe na tzw. szwach zaciekowych, gdzie występowało niebezpieczeństwo przenikania wody deszczowej [18].

Jednymi z pierwszych wagonów całkowicie spawanych były wykonane przez Zakłady Ostrowieckie na zamówienie Sowpoltorgu (ZSRR) wagony

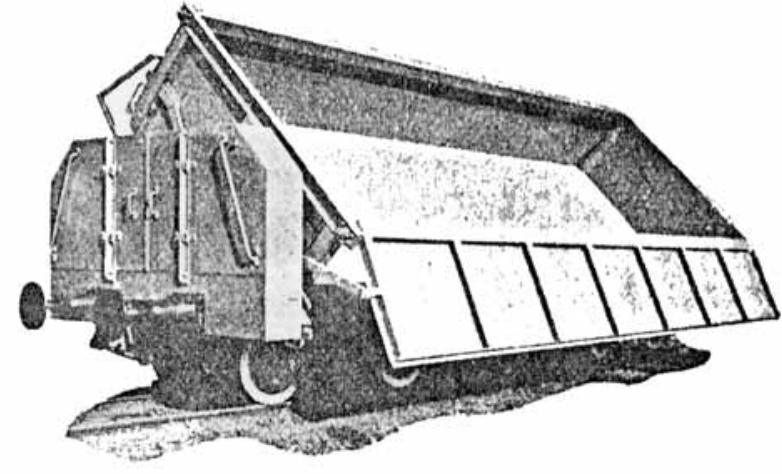

Rys. 10. Wagon przechylony [22]

Fig. 10. Side-dump car [22]

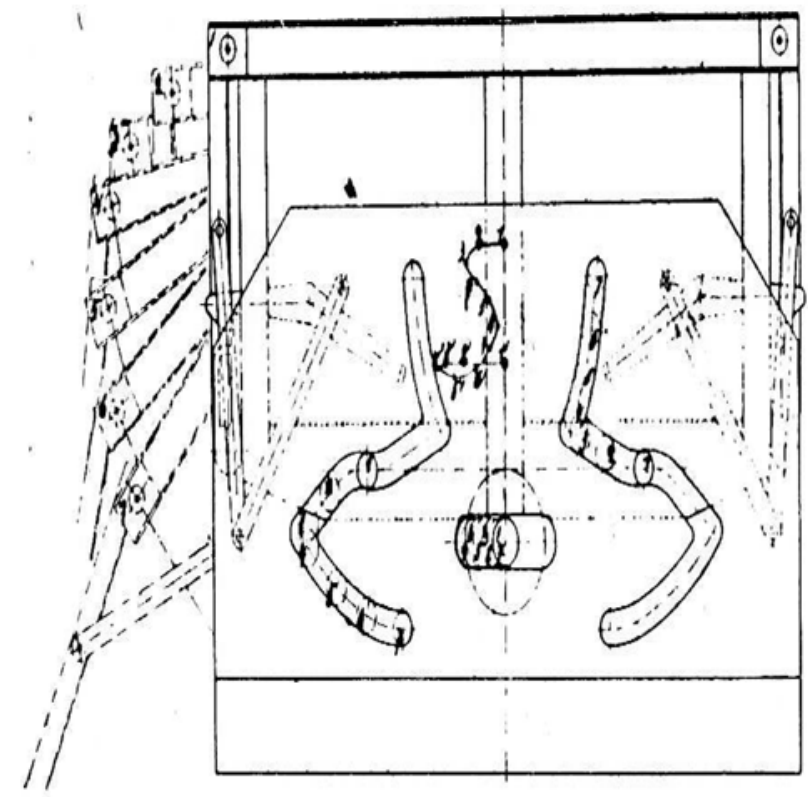

Rys. 11. Schemat urządzenia wywracającego [22]

Fig. 11. Scheme of unloading system [22]

„samoopróżniacze” (samowyładowcze) (rys. 10, 11). Wagony te spawano wyłącznie elektrycznie, stosując elektrody „Jotem”, wytwarzane w Zakładach [22].

W tym samym czasie zbudowano całkowicie spawane wagony osobowe oraz wagony-platformy, a w 1934 r. w Zakładach H. Cegielskiego wykonano pierwszy polski wagon spalinowy dla ruchu pospiesznego, całkowicie spawany [17].

W bardzo szerokim zakresie stosowano spawanie w budowie lokomotyw kopalnianych [19]. Rama lokomotywy, składająca się z blach o grubości 15 i $20 \mathrm{~mm}$ była całkowicie spawana elektrycznie. Stosowano spoiny przerywane w odcinkach $130 / 130 \mathrm{~mm}$ i 150/150 mm, przy grubości spoiny równej 0,7 grubości cieńszej z łączonych blach. Spawane były również budki, zderzaki, sanie pod silnik oraz szkielety poszycia. Do łączenia końcówek elementów przegrzewaczowych oraz belek poprzecznych hamulcowych stosowano zgrzewanie oporowe [19].

W Warszawskiej Sp. Akc. Budowy Parowozów spawalnia była wyposażona w 3 urządzenia do spawania elektrycznego, pracujące na dwie zmiany, i 12 palników 
acetylenowo-tlenowych [20]. Spawanie elektryczne stosowano jedynie do elementów kutych lub walcowanych, gdyż normy urzędowe zabraniały spawania odlewów w produkcji parowozów.

Jednym z elementów spawanych był zbiornik na powietrze stosowany $w$ hamulcach Westinghous'a (rys. 12). Spoinę wzdłużną wykonano acetylenem, a obwodową elektrycznie. Było to związane z większą porowatością i kruchością spoiny uzyskanej łukiem, co w zbiornikach pracujących pod zmiennym ciśnieniem mogło powodować powstawanie pęknięć [20]. Mniej odpowiedzialne zbiorniki, jak garnki wydmuchowe, zbiorniki na ropę i gaz, spawano wyłącznie elektrycznie. Również łukiem spawano kadzie wodne parowozów, dymnice, pierścienie dymnicze służące do usztywnienia dymnicy, skrzydła i narożniki palenisk, końcówki elementów rurowych przegrzewaczy, kątowniki pomostowe, ramki usztywniające podwozie, garnki zlewne przy tendrach itp. [21].

Niezwykle szeroko stosowano spawanie, i to zarówno elektryczne, jak i gazowe, przy produkcji wagonów

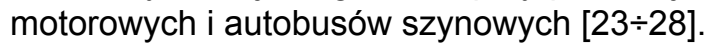

Wagon motorowy był to pojazd szynowy o niezależnym napędzie własnym, osadzony na podwoziu charakterystycznym dla wagonu kolejowego, jednocześnie posiadający pewną liczbę przedziałów do przewożenia pasażerów lub bagażu [24]. Pojazd ten był wyposażony w osie typu kolejowego, z zewnętrznym, w stosunku do łożysk, umieszczeniem resorów i zderzaków, miał koła ze stalowymi bandażami i hamulce działające na obwód kół [23].

W przypadku autobusu szynowego pudło było osadzone na podwoziu typu samochodowego, z kołami umieszczonymi wewnętrznie w stosunku do resorów i hamulcami samochodowymi [23].

Pierwszy wagon motorowy został zbudowany w 1929 r. przez Zakłady Lilpop, Rau i Loewenstein. Był to wagon o napędzie parowym, z kotłem opalanym mieszanką koksowo-węglową. Rok później w Zakładach H. Cegielskiego w Poznaniu rozpoczęto budowę 9 wagonów parowych w oparciu o dokumentację dostarczoną przez angielską firmę Clayton Ltd. a)

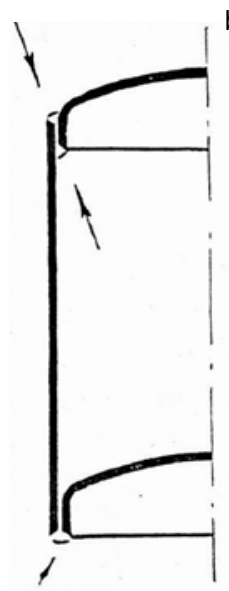

b)

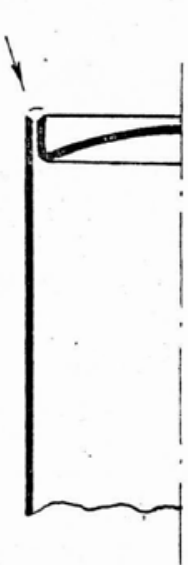

c)

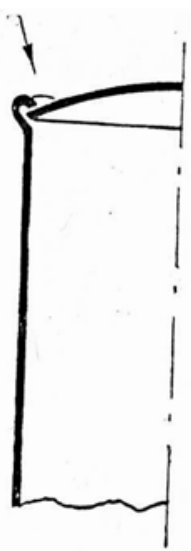

Rys. 12. Sposoby łączenia den zbiorników na sprężone powietrze [20] Fig. 12. Methods of compressed air bottom head joining [20]

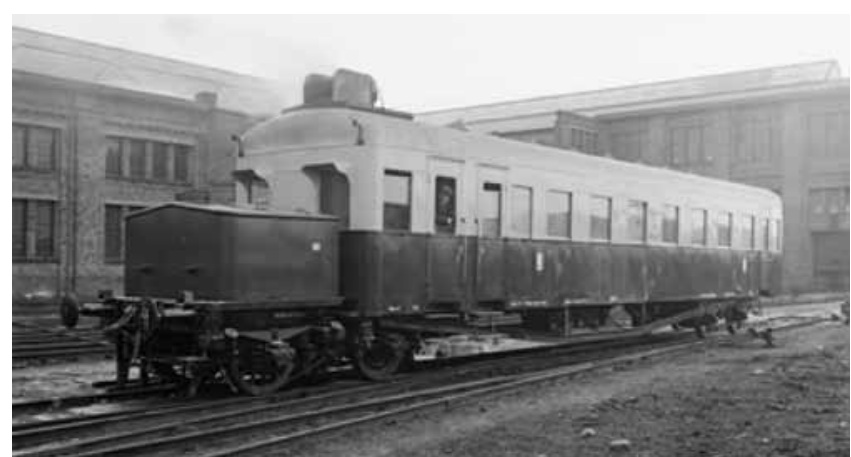

Rys. 13. Wagon motorowy Clayton z silnikiem parowym [30]

Fig. 13. Motor cat with steam engine - Clayton type [30]

(rys. 13). Dokumentację tę jednak zmodyfikowano, wprowadzając wiele zmian i ulepszeń, m.in. zmodernizowano kocioł parowy oraz cały zespół wózka motorowego wraz z napędem i maszyną parową [27, 30].

Niewielka prędkość oraz częste awarie kotłów parowych spowodowały, że zaniechano dalszej produkcji takich wagonów [23, 29].

Kolejne rozwiązanie, napęd elektryczny akumulatorowy, również był niedoskonały, gdyż ze względu na bardzo duży ciężar baterii akumulatorowych nie można było ich stosować w wagonach daleko- i szybkobieżnych [23]. W sumie do 1932 r. w sieci PKP eksploatowano 12 parowych wagonów motorowych, 20 elektrycznych akumulatorowych i 5 wagonów z silnikami benzynowymi [29].

$\mathrm{Na}$ liniach zelektryfikowanych, Warszawa - Żyrardów, Warszawa - Mińsk Mazowiecki, Warszawa - Otwock, kursowały wagony, których napęd stanowiły 4 elektryczne silniki szeregowe prądu stałego o mocy całkowitej 640 kM. Każdy silnik napędzał, za pomocą czołowej przekładni zębatej, jedną oś wagonu. Szkielet pudła wagonu był zbudowany ze słupków oraz krokwi wykonanych z profili prasowanych. Był on pokryty blachą o grubości $2,5 \mathrm{~mm}$. Blachy ze szkieletem oraz między sobą były łączone za pomocą spawania elektrycznego. Również ostoje wózków nośnych były spawane [24].

W połowie lat trzydziestych zaczęto budować wagony motorowe napędzane początkowo silnikiem benzynowym, a następnie wysokoprężnym silnikiem Diesla [23, 27, 29].

Pierwsze wagony z silnikiem Diesla wykonano w fabryce $\mathrm{H}$. Cegielskiego i Zakładach Lilpop, Rau i Loewenstein [26]. Podwozia i pudła wagonowe były wytwarzane w kraju, a silniki, przekładnie i aparaturę sterowniczą sprowadzano z zagranicy. Dopiero w 1934 r. powstała pierwsza całkowicie polska produkcja. Silnik, skrzynię biegów, wózek napędny, hamulec pneumatyczny i aparaturę sterowniczą dostarczyła Warszawska Sp. Akc. Budowy Parowozów, a wózek nośny, podwozie, pudło i całkowite wykończenie wnętrza wykonała fabryka Lilpop, Rau i Loewenstein [26]. Do napędu zastosowano silnik wysokoprężny własnej produkcji, skonstruowany przez prof. Ludwika Ebermana [29]. Przekładnię mechaniczną, przenoszącą moc z silnika na koła pędne, również zaprojektował 
prof. Eberman. Cała konstrukcja pudła wagonu była spawana [26].

Również całkowicie spawany był szkielet stalowy wagonu motorowego zbudowany z profili prasowanych,

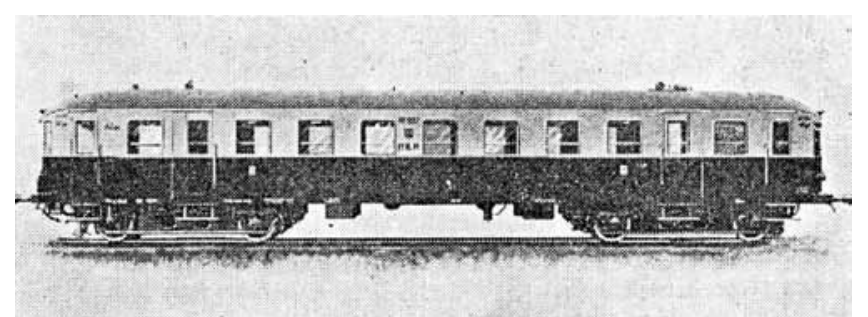

Rys. 14. Wagon motorowy lekkiej konstrukcji szybkobieżny wyprodukowany w Zakładach $\mathrm{H}$. Cegielskiego [31]

Fig. 14. Light structure motor car made by Zakłady H. Cegielski [31]

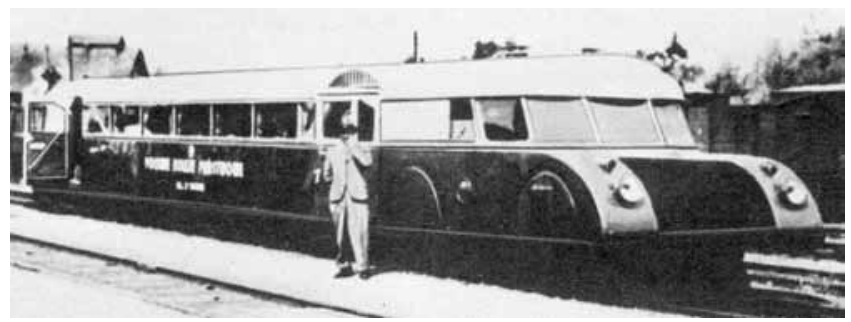

Rys. 15. Wagon motorowy - lukstorpeda [29]

Fig. 15. Main view of motor car called Lux-torpeda a także ostoja wózka z blach i profili normalnych, wykonane w Zakładach $\mathrm{H}$. Cegielskiego [23, 28, 31]. Wagon ten, o 86 miejscach siedzących, rozwijał na trasie Warszawa - Poznań maksymalną prędkość 130 km/h, przy średniej 108 km/h, a na trasie Poznań - Zbąszyń przy tej samej prędkości maksymalnej, średnia prędkość wynosiła 118 km/h (rys. 14) [28, 31].

Do 1939 r. w HCP zbudowano 23 wagony motorowe szybkobieżne z silnikiem spalinowym, w pierwszej wersji z przekładnią mechaniczną, od 1936 r. z przekładnią hydrauliczną, a od 1937 r. elektryczną [31].

W połowie 1936 r. Fabrykę Lokomotyw w Chrzanowie opuścił pierwszy wagon motorowy z rodziny luks -torpeda (rys. 15, 16) [25, 29].

Konstrukcję wagonu oparto na dokumentacji technicznej firmy Steyr-Daimler-Puch A.G., jednak podwyższono o $50 \%$ moc przez zastosowanie silnika wysokoprężnego, zmieniono konstrukcję wózków, układ wentylacyjny i oświetleniowy, a także zmniejszono liczbę miejsc. Dzięki zastosowaniu prasowanych profili stalowych oraz rur ze stali o wysokiej wytrzymałości, aluminium, siluminu i blach karoseryjnych udało się obniżyć ciężar wagonu do 28 t [25].

Szkielet główny wagonu był całkowicie spawany i składał się z dwóch półram połączonych za pomocą

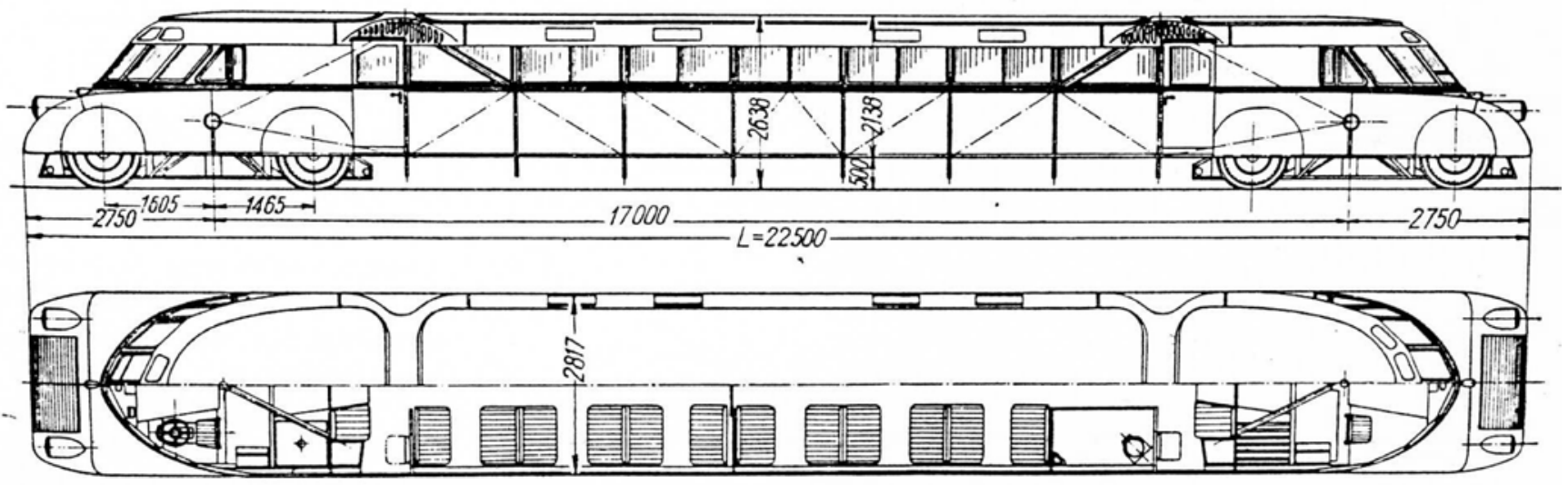

Rys. 16. Wymiary lukstorpedy [25]

Fig. 16. Lux-torpeda dimensions [25]

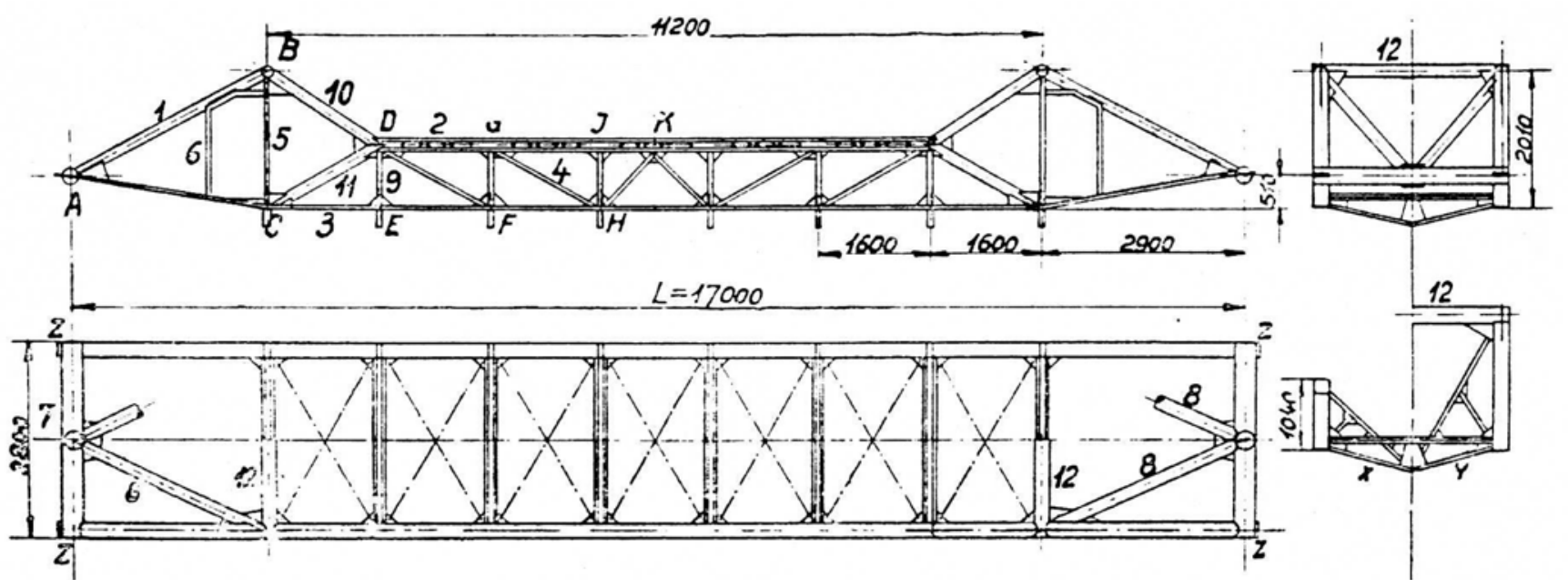

Rys. 17. Szkielet główny spawany w zakładach w Chrzanowie [25]

Fig. 17. Main frame structure welded in Chrzanów [25] 


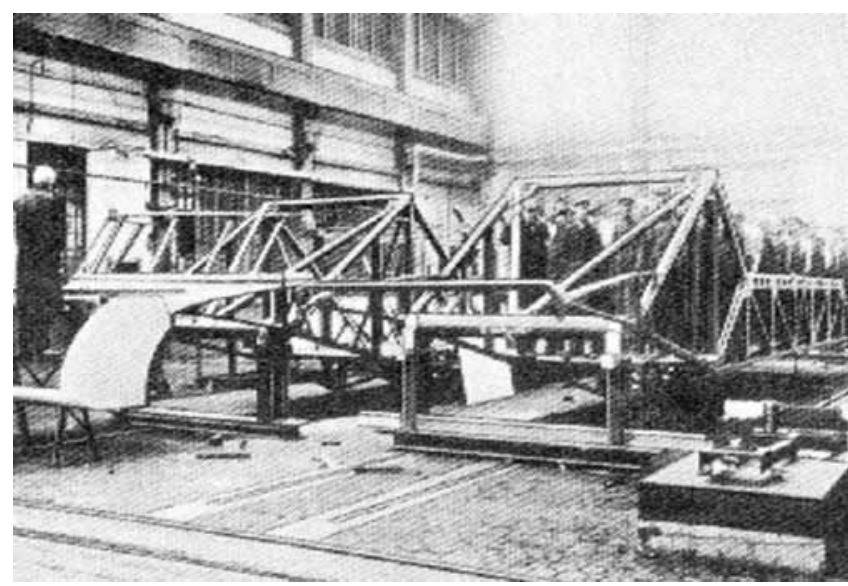

Rys. 18. Próba obciążenia gotowej ramy nadwozia [29]

Fig. 18. Loading test of frame bodywork [29]

6 kratowych poprzecznic $X$ pośrodku, 2 poprzecznic $Y$ i dwóch sekcji rurowych na końcach szkieletu (rys. 17).

Węzły rurowe były spawane płomieniem acetylenowo-tlenowym, pozostałe połączenia wykonano łukiem elektrycznym. Do spawania stosowano elektrody i drut produkcji krajowej, przy czy w tamtym okresie produk- cja elektrod do spawania stali o wysokiej wytrzymałości dopiero się rozpoczynała.

Połączenia cienkich blach (2 i $3 \mathrm{~mm}$ ) wykonywano spoinami jednowarstwowymi, a grubszych wielowarstwowymi, przy użyciu cieńszych elektrod, co pozwoliło uniknąć utwardzenia spoiny i SWC. Ogólnie 75\% spoin wykonano za pomoca spawania elektrycznego, resztę acetylenowo-tlenowego, przy czym przeważnie stosowano spoiny czołowe.

Po zakończeniu robót montażowych i spawalniczych każdy szkielet obciążano, umieszczając na nim pomost z 80 ludźmi, po $10 \div 12$ osób na każdym przęśle (rys. 18) [25].

Do końca 1936 r. w Zakładach w Chrzanowie wykonano pięć wagonów motorowych i skierowano je do obsługi linii Kraków - Warszawa i Kraków - Zakopane, jako luksusowe pociągi ekspresowe [29].

Dwudziestolecie międzywojenne to okres szybkiego rozwoju PKP, wybudowano wtedy wiele nowych linii i połączeń, wprowadzono nowoczesną trakcję spalinową i elektryczną, odbudowano tabor i rozpoczęto budowę nowego w oparciu o przemysł krajowy. Spawanie, jako pewna i szybka metoda łączenia, w sposób istotny przyczyniło się do tego rozwoju.

\section{Literatura}

[1] Strausfogel I.: Warsztaty kolejowe i praktyka warsztatowa. Drukarnia Państwowa, Warszawa 1925, s. 59-63.

[2] Bieliński A.: Spawanie miedzi w kolejnictwie. Inżynier Kolejowy 1939, nr 4, s. 136.

[3] Czaykowski S.: Naprawa żelaznych palenisk kotłów parowozowych za pomocą spawania. Spawanie i Cięcie Metali 1929, nr 6, s. 90-94.

[4] Czaykowski S.: Naprawa ścian miedzianych palenisk parowozów za pomocą spawania acetylenowo-tlenowego. Spawanie i Cięcie Metali 1929, nr 9, s. 3-8.

[5] Lisowski W.: Zastosowanie spawania acetylenowego do naprawy miedzianych palenisk kotłów parowozowych. Spawanie i Cięcie Metali 1931, nr 8, s. 120-123.

[6] Proczkowski M.: Uszkodzenia kotłów parowozowych i ich naprawa. Czasopismo Techniczne 1923, nr 19, s. 281-285.

[7] Dobrowolski Z.: Z dziejów spawalnictwa w Polsce. Przegląd Spawalnictwa 1977, nr 3, s. 49-51.

[8] Nestor spawalnictwa - rozmowa z prof. Dominikiem Syryjczykiem. Przegląd Spawalnictwa 1978, nr 3, s. 21-23.

[9] Proczkowski M.: Uszkodzenia kotłów parowozowych i ich naprawa. Czasopismo Techniczne 1923, nr 20, s. 298-303.

[10] Lisowski W.: Zastosowanie autogenicznego spawania do napraw miedzianych palenisk kotłów parowozowych. Inżynier Kolejowy 1932, nr 6, s. 131-135.

[11] Lisowski W.: Naprawa pękniętych cylindrów parowozowych w Poznańskich Warsztatach PKP. Spawanie i Cięcie Metali 1930, nr 1, s. 3-6.

[12] Lisowski W.: Naprawa pękniętych cylindrów parowozowych w Poznańskich Warsztatach PKP. Spawanie i Cięcie Metali 1930 , nr 2, s. 31-35.

[13] Strausfogel I.: Zastosowanie spawania do naprawy zestawów kołowych taboru kolejowego. Spawanie i Cięcie Metali 1928, nr 4, s. 5-9.

[14] Szejnowski P.: Naprawa obręczy kół parowozowych. Spawanie i Cięcie Metali 1929, nr 3, s. 46.
[15] Tułacz P., Golling F.: Spawane wagony kolejowe. Inżynier Kolejowy 1932, nr 9, s. 198-200.

[16] Budowa wagonów osobowych spawanych. Spawanie i Cięcie Metali 1928, nr 1, s. 5-9.

[17] Świderski Z.: Działalność Centralnego Ośrodka Badań i Rozwoju Techniki Kolejnictwa w zakresie spawalnictwa. Przegląd Spawalnictwa 1980, nr 11, s. 5.

[18] Sznerr A., Dobrowolski Z.: Spawanie. Spawanie i Cięcie Metali 1932, nr 5-6, s. 81-82.

[19] Szumowski A.: Zastosowanie spawania i cięcia metali w budowie lokomotyw. Spawanie i Cięcie Metali 1934, nr 6, s. 107-109.

[20] Daniszewski W.: Spawanie w Warszawskiej Sp. Akc. Budowy Parowozów. Spawanie i Cięcie Metali 1930, nr 5, s. 82-84.

[21] Daniszewski W.: Spawanie w Warszawskiej Sp. Akc. Budowy Parowozów. Spawanie i Cięcie Metali 1930, nr 6, s. 109-112.

[22] Wagony samoopróżniacze 30-tonowe dla Z.S.R.R. Inżynier Kolejowy 1933, nr 6, s. 147-149.

[23] Dakura S.: Wagony motorowe. Mechanik 1934, z. 11, s. 221-229.

[24] Zieliński J.: Elektryfikacja węzła kolejowego warszawskiego. Wiadomości Elektrotechniczne 1937, nr 1, s. 13-14.

[25] Szumowski A.: Lekkie i szybkobieżne całkowicie spawane wozy motorowe (lux-torpedy) na PKP. Przegląd Mechaniczny 1936, nr 15-16, s. 561-569.

[26] Gutowski M.: Polski wagon silnikowy. Przegląd Techniczny 1935, nr 5, s. 93-95.

[27] Popowicz S.: Budowa wagonów motorowych w Polsce i wymagania ruchu. Przegląd Mechaniczny 1935, nr 23, s. 802-807.

[28] Tymiński T.: Wprowadzenie krajowych wozów silnikowych na PKP. Życie Techniczne 1935, nr 8, s. 232-236.

[29] Pokropiński B.: Lux-torpeda PKP. WKiŁ, Warszawa 1988.

[30] www.naukaitechnika.pl/archiwum_techniki/pdf

[31] Tatara F.: Budowa wagonów w Zakładach H. Cegielski. Biuletyn Techniczny 1959, nr 7-8, s. 57-67. 